\title{
Analisis finansial usaha budidaya rumput laut berdasarkan uji pertumbuhan bibit dengan dengan jarak ikat berbeda
}

\section{(Financial analysis of seaweed cultivated with different seed tight)}

\author{
Agus Gaghaube, Edwin L.A. Ngangi, Joppy D. Mudeng
}

\begin{abstract}
The purpose of this study was to analyze the financial feasibility of the test Kappaphycus alvarezii seaweed cultivated with different seed tight distance. The study was conducted in Talengen Bay, Tabukan Tengah, Regency of Sangihe Islands from April to May 2013. Seed tight distance as treatment consisted of $A=10 \mathrm{~cm}, B=20 \mathrm{~cm}$, and $C=30 \mathrm{~cm}$. Seaweed was cultivated using surface long-line with initial weight of seed per bond was 100 g. Containers measuring $16 \times 10 \mathrm{~m}^{2}$ were divided into nine small plot of $4 \times 2 \mathrm{~m}^{2}$, each with three ris. The trial was conducted for over 42 days, and weighed every 14 days. Results obtained displayed the best growth was achieved at treatment $C$ (distance of $30 \mathrm{~cm}$ ) followed by distance of $20 \mathrm{~cm}$, and $10 \mathrm{~cm}$. Analysis of total revenue (total profit) found that seedlings $10 \mathrm{~cm}$ distance seed tight was the highest, followed by distance $20 \mathrm{~cm}$ and $30 \mathrm{~cm}$. Income level analysis results (profit rate) found that $30 \mathrm{~cm}$ distance was the highest, followed by distance $10 \mathrm{~cm}$ and $20 \mathrm{~cm}$. As conclusion, the cultivation of seaweed $K$. alvarezzi was financially viable based on $30 \mathrm{~cm}$ seed tight distance.
\end{abstract}

Keywords: Kappaphycus alvarezii, total profit, profit rate, Talengen Bay.

\section{PENDAHULUAN}

Perairan pesisir Kabupaten Kepulauan Sangihe merupakan salah satu wilayah yang sangat potensial untuk pengembangan marikultur (budi daya laut). Salah satu pilihan untuk usaha perikanan marikultur di kabupaten ini yaitu budi daya rumput laut. Budi daya rumput laut di samping berteknologi sederhana juga kebutuhan modal usaha yang dibutuhkan relatif sedikit. Jenis rumput laut yang cocok dikembangkan ialah jenis rumput laut Kappaphycus alvarezii. Menurut Winarno (1990) bahwa jenis rumput laut ini diperlukan untuk usaha industri, karena kappa karaginannya sangat dibutuhkan sebagai bahan stabilisator, bahan pengental, pembentuk gel, dan pengelmusi. Selanjutnya Sediadi \& Budihardjo (2000) menyatakan bahwa budi daya rumput laut penting peranannya dalam peningkatan produksi perikanan untuk memenuhi kebutuhan pangan dan gizi masyarakat.

Usaha budi daya rumput laut jika tidak dikelolah dengan baik dan tidak memperhatikan kelestarian serta daya dukung lingkungan, maka dapat menurunkan kuantitas dan kualitas 
produksinya. Salah satu yang harus diperhatikan dalam budi daya rumput laut yaitu jarak ikat antar bibit. Jarak ikat yang tepat akan memacu pertumbuhan, meningkatkan efisiensi pemakaian lahan, panen tepat waktu dan memberikan keuntungan waktu, tenaga, dan biaya.

Penelitian tentang jarak ikat antar bibit rumput laut sudah banyak dilakukan, tetapi hanya sampai pada analisis pertumbuhannya. Analisis kelayakan usaha, dalam hal ini analisis finansial, dibutuhkan sebagai bahan acuan dalam penerapan di lapangan. Jarak ikat bibit rumput laut berhubungan dengan pola tanam dan kondisi lingkungannya yang berbeda-beda. Menurut Ngangi (2001) bahwa jarak ikat antar bibit yang tidak tepat akan berpengaruh pada hasil produksi. Jarak ikat bibit yang berbeda akan berdampak pada kebutuhan biaya untuk pemakaian tali dan bibit, serta upah untuk mengikat bibit, pemeliharaan, panen, dan pascapanen.

\section{BAHAN DAN METODE}

\section{Tempat dan waktu}

Penelitian dilakukan di Perairan Teluk Talengen Kecamatan Tabukan Tengah Kabupaten Kepulauan Sangihe. Penelitian dilakukan mulai bulan April sampai Mei 2013. Percobaan dirancang menurut rancangan acak lengkap (RAL) dengan 3 perlakuan dan 3 kali ulangan.

\section{Pengumpulan data}

Faktor yang diuji yaitu pertumbuhan dengan perlakuan sebagai berikut: $\mathrm{A}=$ jarak ikat bibit $10 \mathrm{~cm}, \mathrm{~B}=20$ $\mathrm{cm}, \mathrm{C}=30 \mathrm{~cm}$. Wadah yang digunakan berukuran 16 x $10 \mathrm{~m}^{2}$, dibagi dalam 9 petakan $4 \times 2 \mathrm{~m}^{2}$. Pada tiap petakan terdapat 3 tali ris yang terdiri dari 5 ikatan bibit dengan jarak ikat sesuai perlakuan.
Pengambilan data pertumbuhan dilakukan setiap 14 hari selama 42 hari. Data hasil penimbangan dikumpulkan untuk menghitung pertumbuhan mutlak.

\section{Analisis data}

Pertumbuhan mutlak menunjukkan selisih antara berat akhir dan berat awal selama masa pemeliharaan Zoneeveld (1991) dengan rumus :

$$
\Delta \mathbf{W}=\mathbf{W}_{\mathbf{t}}-\mathbf{W}_{\mathbf{0}}
$$

Dimana,

$\Delta \mathrm{W}=$ Pertumbuhan mutlak dalam berat (gram);

$\mathrm{W}_{\mathrm{t}}=$ Berat rata-rata rumput laut uji pada akhir percobaan;

$\mathrm{W}_{0}=$ Berat rata-rata rumput laut uji pada awal percobaan.

Analisis finansial menurut Djamnin (1993) yaitu suatu ukuran yang dipakai sebagai dasar pengambilan keputusan untuk melakukan investasi dalam kriteria undiscounted yaitu total profit, dengan pengertian keuntungan absolut $(\pi)$. Apabila hasil perhitungan memberikan angka positif $(\pi=+)$ maka investasi dinyatakan layak (“go”), kalau hasilnya negatif ( $\pi=-)$ maka investasi dinyatakan tidak layak (“reject”). Perhitungan total profit, dengan pengertian keuntungan absolut, yaitu:

$$
\pi=\mathrm{TR}-\mathrm{TC}
$$

Tingkat keuntungan (profit rate) dihitung berdasarkan rumus:

$$
\text { Profit rate }=\frac{\pi}{T C} x 100
$$

Dimana,

$\pi \quad=$ total profit/keuntungan absolut;

$\mathrm{TR}=$ total revenue (jumlah seluruh penerimaan);

$\mathrm{TC}=$ total cost (jumlah seluruh biaya).

Apabila profit rate di atas inflation rate (\%) maka budi daya rumput laut $K$. 
alvarezii layak diusahakan. Inflation rate yang digunakan, sesuai data dari Bank Indonesia pada bulan Agustus 2013 yaitu 8\%. Hasil analisis profit rate setiap perlakuan diranking mulai dari nilai tertinggi sampai terendah. Pengambilan keputusan usaha budi daya rumput $K$. alvarezii berdasarkan ranking yang didapat dari perlakuan yang memberikan profit rate tertinggi.

\section{HASIL DAN PEMBAHASAN}

\section{Pertumbuhan utlak}

Hasil yang didapat selama satu siklus pemeliharaan (42 hari) rumput laut Kappaphycus alvarezii menunjukan peningkatan pertumbuhan pada setiap satuan percobaan. Hasilnya menunjukkan bahwa pertumbuhan tertinggi pada jarak ikat bibit 30 cm (260,74 gram), diikuti jarak ikat $20 \mathrm{~cm}$ (200,54 gram) dan jarak ikat $10 \mathrm{~cm}$ (155,70 gram).

Keberhasilan usaha budi daya rumput laut sangat ditentukan oleh kondisi lingkungan perairan lahan budi daya. Menurut Mubarak (1981) dalam Rumpilu (2010), pergerakan air yang sedikit menyebabkan suplai makanan yang diserap oleh rumput laut juga berkurang. Jarak ikat yang tidak terlalu berdekatan akan menimbulkan pertumbuhan rumput laut meningkat dengan cepat karena pergerakan air lebih baik sehingga penyerapan makanan tidak terhambat. Selain itu rumput laut yang berjarak tanam yang tepat tidak akan saling menghalangi dalam proses fotosintesis. Demikian yang terjadi pada penelitian ini bahwa jarak ikat $30 \mathrm{~cm}$ memberikan pertumbuhan tertinggi dibandingkan dengan jarak ikat $20 \mathrm{~cm}$ dan $10 \mathrm{~cm}$.

\section{Analisis Kelayakan}

Keberhasilan usaha budi daya rumput laut tidak hanya tergantung pada pertumbuhan melainkan juga dari hasil penjualan atau pemasaran. Asumsi teknis dan parameter keuangan usaha budi daya rumput laut Kappaphycus alvarezii ini didasarkan pada pertumbuhan mutlak pada jarak ikat bibit yang berbeda.

Kebutuhan dana investasi usaha budi daya rumput laut pada tiga perlakuan sama, yaitu sebesar Rp10.980.000.00, sedangkan kebutuhan operasional pada tiap perlakuan berbeda. Pada perlakuan A $(10 \mathrm{~cm})$ kebutuhan dana operasional sebesar Rp58.858.000,00, perlakuan B (20 cm) sebesar Rp48. 066.500,00 dan perlakuan C $(30 \mathrm{~cm})$ sebesar Rp29.120.500,00.

Berdasarkan kebutuhan dana dan hasil pertumbuhan rumput laut $K$. alvarezii, didapat bahwa jarak ikat bibit 10 $\mathrm{cm}$ memberikan pendapatan atau keuntungan tertinggi (Rp89.412.000,00), diikuti perlakuan B jarak ikat bibit $20 \mathrm{~cm}$ (Rp54.952.500,00), dan C jarak ikat bibit 30 cm (Rp546.525.000,00). Terlihat bahwa pertumbuhan terbaik (perlakuan C) tidak selalu memberikan keuntungan yang tinggi, bahkan perlakuan A yang memberikan pertumbuhan terendah memiliki keuntungan paling tinggi (Gambar 1). Hal ini disebabkan pada asumsi bahwa jarak ikat bibit $10 \mathrm{~cm}$ walaupun pertumbuhannya rendah tetapi jumlah ikatannya paling banyak, yaitu 100.000 rumpun per hektar. Produksi jarak ikat bibit $10 \mathrm{~cm}$ per hektar akan lebih banyak dibandingkan dengan jarak ikat 20 cm yang hanya 50.000 rumpun per hektar. Apalagi jarak ikat bibit $30 \mathrm{~cm}$ yang hanya bisa diikat 33.300 rumpun per hektar. 


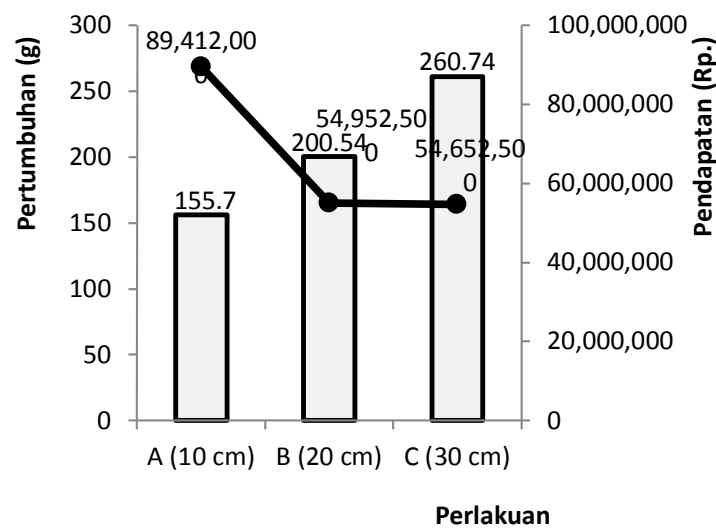

Gambar 1. Hubungan antara pertumbuhan dan pendapatan

Walaupun demikian, dari analisis profit rate yang dibandingkan dengan pertumbuhan setiap perlakuan didapat bahwa tingkat keuntungan tertinggi pada jarak ikat bibit $30 \mathrm{~cm}$, diikuti $10 \mathrm{~cm}$ dan $20 \mathrm{~cm}$, masing-masing yakni 53,77\%, 46,84\%, dan 43,77\% (Gambar 2). Profit rate (tingkat keuntungan) merupakan selisih nilai yang didapat dari profit margin atau break event point (BEP), yaitu nilai yang diharapkan dari suatu usaha (balik modal). Nilai balik modal merupakan nilai saat mencapai pengembalian biaya.

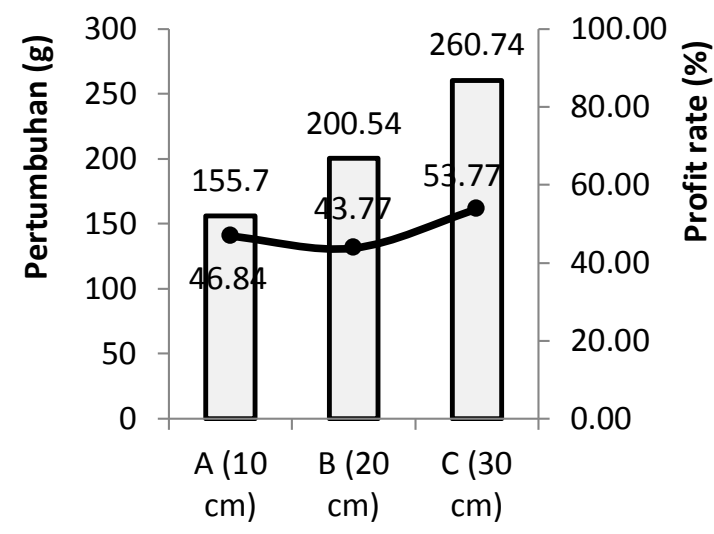

Perlakuan

Gambar 2. Hubungan antara pertumbuhan dan profit rate
Biaya dari masing-masing perlakuan yang berbeda sangat mempengaruhi analisis profit rate. Gambar 3 menunjukkan bahwa perlakuan A membutuhkan total dana yang paling besar (Rp190.140.000,00), diikuti perlakuan B (Rp123.294.000,00), kemudian perlakuan C (Rp104.196.000,00), ketiganya untuk tiga tahun usaha. Kebutuhan dana seperti pada Gambar 3 yang menyebabkan profit rate pada perlakuan $\mathrm{C}$ menjadi paling tinggi, apalagi dihubungkan juga dengan pertumbuhannya yang paling baik. Perlakuan A walaupun memberikan pendapatan yang paling tinggi tetapi membutuhkan dana yang paling besar. Pertumbuhannya juga yang paling rendah, dimana hanya jumlah ikatan bibit (rumpun) per hektar yang banyak sehingga pada perhitungan awal pendapatan terlihat paling baik.

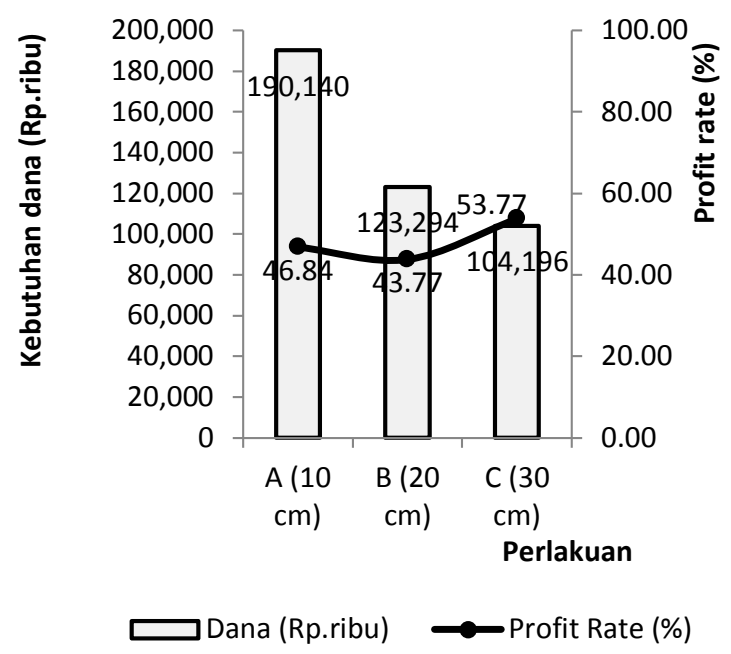

Gambar 3. Hubungan antara kebutuhan dana dan profit rate

Profit rate untuk semua perlakuan berada di atas inflation rate, yaitu 8\% (BI, Agustus 2013), artinya bahwa semua perlakuan layak untuk diusahakan. Bahan acuan untuk budidaya rumput laut Kappaphycus alvarezii di Teluk Talengen 
sebaiknya menggunakan jarak ikat bibit 30 cm (perlakuan C). Jarak ikat bibit $10 \mathrm{~cm}$ (perlakuan A) merupakan pilihan berikutnya asalkan memiliki dana yang besar dan diusahakan pada lahan yang lebih luas. Perlakuan A dapat menjadi pilihan utama apabila yang menjadi sasaran dalam budi daya rumput laut ialah pemberdayaan masyarakat dan penyerapan tenaga kerja, khususnya pada masyarakat pesisir dan pulau-pulau kecil. Hal ini didasarkan pada asumsi bahwa perlakuan A (jarak ikat bibit $10 \mathrm{~cm}$ ) membutuhkan tenaga kerja yang lebih banyak dengan waktu kerja yang lebih lama.

\section{KESIMPULAN}

- Jarak ikat bibit $30 \mathrm{~cm}$ rumput laut jenis Kappaphycus alvarezii memberikan pertumbuhan terbaik pada bulan April sampai Mei di Teluk Talengen Kecamatan Tabukan Tengah Kabupaten Kepulauan Sangihe.

- Jarak ikat bibit $30 \mathrm{~cm}$ menghasilkan tingkat pendapatan (profit rate) paling tinggi sehingga merupakan pilihan pertama dalam usaha budi daya rumput laut Kappaphycus alvarezii di Teluk Talengen Kecamatan Tabukan Tengah Kabupaten Kepulauan Sangihe.

\section{UCAPAN TERIMA KASIH}

Disampaikan terimah kasih kepada Edwin O. Langi bersama mahasiswa Teknologi Budidaya Ikan Politeknik Negeri Nusa Utara Tahuna yang sudah membantu dalam pelaksanaan penelitian.

\section{DAFTAR PUSTAKA}

Djamin Z. 1993. Perencanaan dan analisa proyek. Lembaga Penerbit Fakultas Ekonomi Universitas Indonesia, Jakarta.

Ngangi E. 2001. Kajian intensifikasi dan analisis finansial usaha budi daya rumput laut Kappaphycus alvarezii di Desa BentenanTumbak Kecamatan Belang Propinsi Sulawesi Utara.[Tesis]. Bogor: Institut Pertanian Bogor

Rumpilu J. 2010. Pertumbuhan rumput laut Kappaphycus alvarezii pada perbedaan berat awal dan kedalaman perairan Wealilir Kabupaten Maluku Tenggara, Propinsi Maluku

Sediadi, Budihardjo. 2000. Rumput laut komoditas unggulan. Grasindo.Jakarta

Winarno 1990. Teknologi pengolahan rumput laut. Pustaka sinar harapan.Jakarta

Zonneveld dkk. 1991. Prinsip-prinsip budidaya ikan. Penerbit PT Gramedia Pustaka Utama, Jakarta. 